\title{
Introduction: Neo-Institutional Look at Modern Socio-Economic Development
}

Modern society and the economy face new and increasingly serious global challenges, the efficient response to which can only be provided by a progressive and reliable institutional framework of business systems. This necessitates the transformation of existing institutions and the creation of new ones. The COVID-19 pandemic is one of the most serious challenges that humanity faced for the first time in recent decades. Combating the virus threat required accumulation of all efforts and resources, which required strengthening the health care institution and the public health services institution.

Thanks to high-tech medicine based on Artificial Intelligence, vaccines for a new coronavirus have been developed around the world within the shortest possible time; some of them are already in use, while others are at different (including final) testing stages. From the perspective of socio-economic development, the pandemic not only called for increasing funding and monitoring public health services but also necessitated severe restrictions on human interaction (social distancing) which hindered the normal operation of business structures and caused a systemic crisis of business systems.

Although humankind is about to defeat the pandemic soon, the aftershocks of socio-economic crisis that emerged with it in the background will probably be clearly manifested in the years to come, and high risk of emergence of new infectious diseases will maintain, which will make it possible to define the overall level of the virus threat for humankind as high. In this regard, the outstanding and coherent activities of international organizations, particularly the World Health Organization (WHO), which have established statistical recording of the COVID-19 and related manifestations in society and the economy within the shortest possible time and provided useful recommendations on crisis management, are particularly noteworthy. As a result, the situation was made controllable, more predictable (less uncertain) and manageable. The operation of these institutions must continue in the years to come to maintain the stability of society and the economy, to ensure prevention and early recognition of the virus threat in the future as well as combating this threat.

Another significant challenge of the modern age is the focus on sustainable development. International organizations, headed by the United Nations Organization (UN), are also of great concern here, but the primary responsibility rests with state (national) regulators and corporate entities. In this regard, the institution of corporate social responsibility has taken on new significance, thanks to which sustainable development goals have gained massive support in the business environment, and humankind has made meaningful progress in their implementation.

The intellectualization of business activities should also be pointed out as a key challenge. Intelligent machines have already become a part of the modern age, which

https://doi.org/10.1515/9783110699869-202 
becomes increasingly prevalent and widely recognized. The approach of a high-tech future requires not only new technologies but also new competences. The digitalization of society and the economy requires modernization of education and learning not only new professional competences, digital ones in particular, but also new creative competences. This implies intensive development of a higher education institution.

This book, which consists of four parts, has considered all abovementioned challenges and institutions necessary for an effective response to them. Part I considers the institutions of strategic foreign economic interaction and recent experience of their operation in the modern world economy. It has analyzed the strategic directions of international economic cooperation, examined the impact of multipolar globalization on the labor market and international cooperation through the example of various countries (Russia, Germany, Mongolia) and integration associations of countries (Eurasian Economic Union, EEU).

Part II deals with the basic institutional principles of state regulation in response to new global challenges of the modern age. The institutions of state regulation of competition, modernization of taxation, and socio-economic crisis management are examined here. The "COVID Law" phenomenon has been identified and discovered. Part III reveals the institutions of the "knowledge economy" and a competence-based approach to their development. It describes the institutions of development of professional and creative competences based on the education system.

Part IV has presented an institutional framework for corporate governance to accelerate economic growth. It includes the description of practices of enterprises from different countries (Uzbekistan, Russia) in using logistics, corporate social responsibility, corporate accounting and information management institutions. All parts are closely related to each other, they enhance and complement each other; as a result, a holistic view of the new institutions for socio-economic development has been formed in the book. 